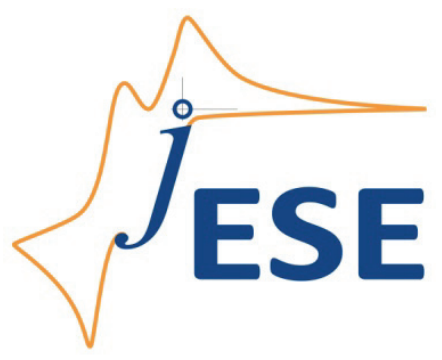

Open Access : : ISSN 1847-9286 www.jESE-online.org

Original scientific paper

\title{
Electrochemical degradation of Reactive Brilliant Red K-2BP on Ti/RuTilrSnMn oxide anode in a batch cell
}

\author{
LUO JIANCHENG*, YANG JIE*, LI WEISHAN*,**,***,凶 HUANG QIMING*,**,*** and XU \\ HONGKANG****
}

*School of Chemistry and Environment, South China Normal University, Guangzhou 510006, China

**Key Laboratory of Electrochemical Technology on Energy Storage and Power Generation of Guangdong Higher Education Institutes, South China Normal University, Guangzhou 510006, China

***Engineering Research Center of Materials and Technology for Electrochemical Energy Storage (MOE), South China Normal University, Guangzhou 510006, China

****Dongguan Hongjie Environmental Technologies Ltd, Dongguan 523039, China

${ }^{\square}$ Corresponding Author: E-mail: liwsh@scnu.edu.cn; Tel.: +86-020-39310256; Fax: +86-020-39310256

Received: July 06, 2012; Published: November 10, 2012

\begin{abstract}
Electrochemical degradation of Reactive Brilliant Red K-2BP on Ti/RuTilrSnMn oxide anode in chloride containing solution was investigated by voltammetry and electrolysis in a batch cell. It is found that the degradation mechanism of $\mathrm{K}-2 \mathrm{BP}$ on Ti/RuTilrSnMn oxide anode involves an indirect electrocatalytic oxidation, in which K-2BP is oxidized by the electrochemically generated active chlorine. This degradation reaction follows pseudo-first order reaction kinetics. Ti/RuTilrSnMn oxide exhibits excellent electrocatalytic activity toward the generation of active chlorine from chloride. Hence, $K-2 B P$ can be electrochemically degraded effectively in chloride containing solution. The decolorization efficiency was found to increase with the decrease in $\mathrm{pH}$ and with the increase in current density, $\mathrm{NaCl}$ concentration, temperature, and flow rate of the solution.
\end{abstract}

\section{Keywords}

Decolorization; Electrooxidation; Active chlorine

\section{Introduction}

Dye effluent in textile industry is an environmental concern due to its huge quantity, dark color, low biodegradability, and potential toxicity to aquatic life. Various treatment methods have been proposed and/or tested to effectively degrade the effluent, including biological treatment [1-7], 
photocatalysis [8-10], ozonation [11,12], wet oxidation [13,14], Fenton reaction $[15,16]$, electrochemical coagulation [17-19], and electrochemical oxidation [20-31].

Compared with other methods for the treatment of the textile effluent, electrochemical technologies are easy to operate, highly efficient and environmentally friendly. Electrooxidation has been widely used to treat various industrial wastewaters, including the wastewaters containing dye, urea, phenol, molasses, microcystins, tannery, olive oil, pesticide, etc. [20,26-32].

There are two mechanisms for the electrooxidation treatment of wastewater, direct and indirect oxidation. In the direct oxidation mechanism, pollutants are oxidized directly on the anode surface. In that case, there is no any other substance involved, except the electrons in the electrooxidation of pollutants. However, pollutants and their degraded products are usually adsorbed on the anode, leading to the low degradation efficiency and the complicated treatment technology for the anode cleaning. In the indirect mechanism, pollutants are oxidized in a bulk solution by a medium, such as active chlorine and hydroxyl radicals electrogenerated in-situ on the anode surface, and thus the adsorption of pollutants and their degradation products can be avoided. The medium is utilized immediately after its electrogeneration. Therefore, indirect electrooxidation can lead to a high efficiency of degradation.

Dimensionally stable anode (DSA) was originally designed for chlor-alkali industry [33]. DSA has long lifetime and it is much cheaper than noble metal anodes such as platinum. It has been widely used in a wastewater treatment research and development. Ruthenium- and iridium- oxides are the main composition of DSAs. They exhibit good electrocatalytic activity for active chlorine generation and oxygen evolution. Based on these two oxides, many composite oxides have been developed for DSA use. For example, ruthenium-based oxides, especially $\mathrm{Ti} / \mathrm{Ti}_{0.7} \mathrm{Ru}_{0.3} \mathrm{O}_{2}$, have been reported to treat the refractory effluent $[26,28,30,31]$.

Reactive Brilliant Red K-2BP (K-2BP) is an azo-dye which is extensively used in the textile industry. Its molecule structure is shown in Fig. 1. K-2BP is resistant to either biological or photodegradation. The solution containing $\mathrm{K}-2 \mathrm{BP}$ is brilliant red and can be distinguished even in trace concentration by naked eye.

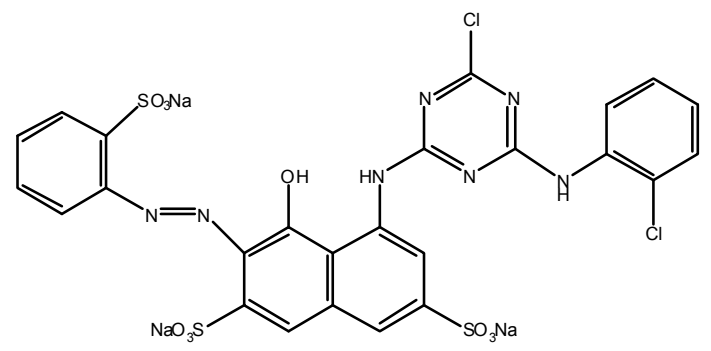

Figure 1. Molecule structure of Reactive Brilliant Red $K-2 B P$

In this work, a coating on titanium substrate of composite oxides based mainly on Ru and Ir, $\mathrm{Ti} /$ RuTilrSnMn oxide, was used as an anode to degrade K-2BP by the indirect electrooxidation with electrochemically generated active chlorine as the medium. The parameter effects of electrolytic conditions on the degradation efficiency were investigated and the degradation mechanism was discussed.

\section{Experimental}

\section{Reagents and solutions}

Deionized water was used for the preparation of all solutions. Sodium hydroxide and sulfuric acid were used to adjust $\mathrm{pH}$ of the solution. Sodium chloride was used for the generation of active 
chlorine. Sodium sulfate and sodium nitrate were also used as electrolytes for comparison. All the reagents were analytical reagents and purchased from Sinopharm Chemical Reagent Co., Ltd, China. The commercially used textile azo dye, mainly containing Reactive Brilliant Red K-2BP, was purchased from the local market. All the chemicals were used as received without further purification.

\section{Electrolysis cell}

The experiments were carried out in an un-divided filter-press cell (Fig. 2) with constant current at fixed temperature of $30{ }^{\circ} \mathrm{C}$ except otherwise stated. The dye-containing solution was supplied from the feed tank $(250 \mathrm{~mL})$ to the electrolysis cell by a peristaltic pump. The treated water can be recycled back to the solution tank if necessary. Constant current was provided by a D. C. power supply (363, EG\&G). A magnetic stirrer was used to keep the solution mixed and a thermostatic water bath was employed to control the temperature. The solution volume was $200 \mathrm{~mL}$ with 100 $\mathrm{mg} / \mathrm{L} \mathrm{K-2BP}$. The anode (Ti/RuTilrSnMn oxide) was supplied by Guangzhou Etsing Plating Research Institute, which was prepared by coating the composites (the compounds containing Ru, Ti, Ir, Sn, and $\mathrm{Mn}$ ) on Ti plate and treated under high temperature. The cathode was made from stainless steel (SUS304). Both electrodes, anode and cathode were of the same size of geometric area having $21 \mathrm{~cm}^{2}$ exposed to the solution. The gap between the two electrodes was $10 \mathrm{~mm}$. Before each set of experiments, the anode was immersed in absolute alcohol for $5 \mathrm{~min}$ and then rinsed with deionized water. The cathode was polished with sandpaper (2000), then immersed in $1.0 \mathrm{M}$ $\mathrm{HCl}$ solution for $5 \mathrm{~min}$, and finally rinsed with deionized water.

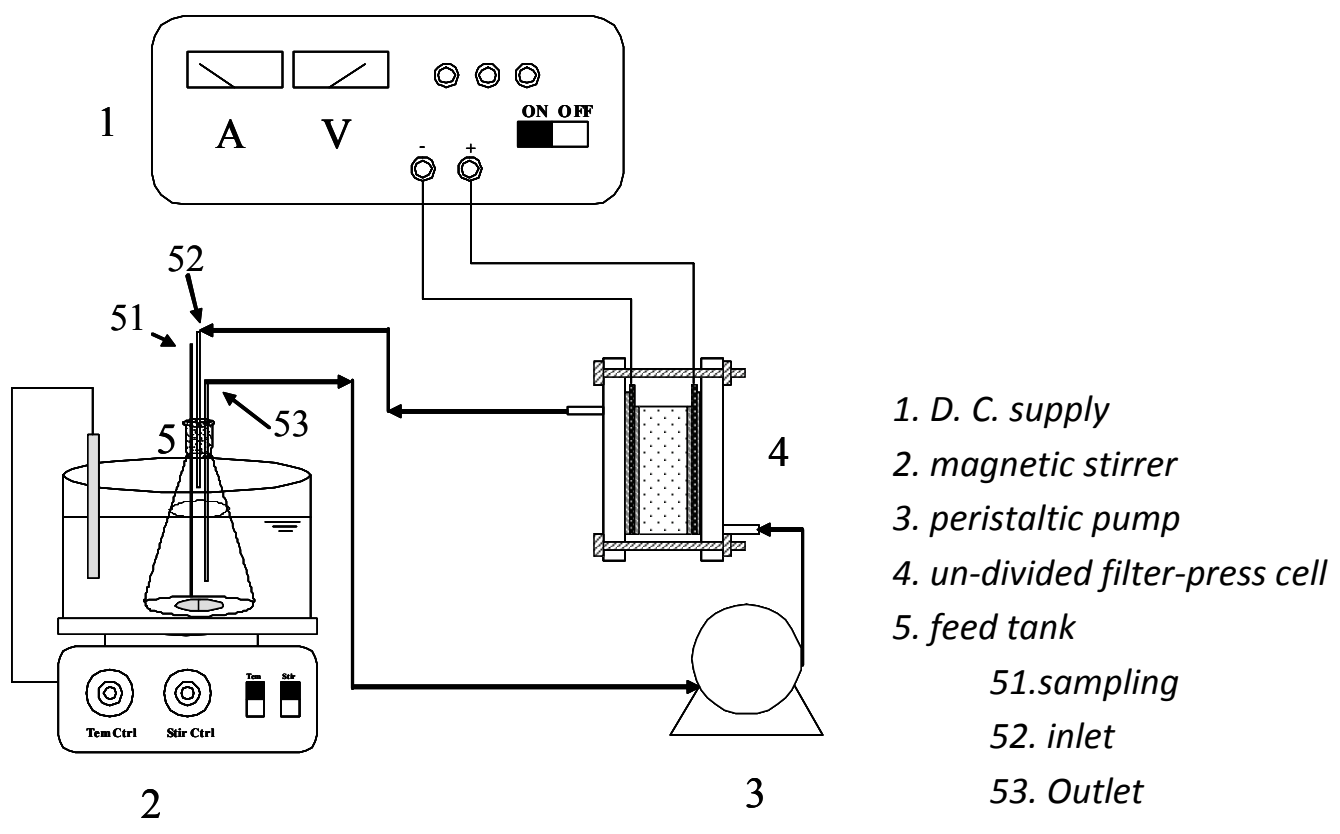

Figure 2. Schematic diagram of experimental setup for the degradation of $K-2 B P$

\section{Analytical procedure}

At desired time interval, the dye solution was sampled and filtered through a $0.45 \mu \mathrm{m}$ millipore membrane. Several drops of saturated sodium sulfite solution were added into the sample to prevent further oxidation of the dyestuffs and their intermediates by residual chlorine. The samples were analyzed immediately after their collection using a Shimadzu UV-1700 double-beam spectrophotometer. 
The concentration of $\mathrm{K}-2 \mathrm{BP}$ in the samples was determined from the UV-Vis absorbance recorded at $520 \mathrm{~nm}(\max )$ and the degradation efficiency $(A / \%)$ was calculated according to [28]:

$$
A / \%=\frac{\left(A_{0}-A_{\mathrm{t}}\right)}{A_{0}} 100
$$

where $A_{0}$ and $A_{\mathrm{t}}$ are the absorbance of the solution before and after electrolysis, respectively.

\section{Voltammetric measurements}

In order to understand the degradation mechanism of K-2BP on Ti/RuTilrSnMn oxide anode, linear and cyclic voltammograms were obtained by using a three-electrode cell (Solartron 1470E, Solartron Co., Ltd.). A Pt plate was used as the counter electrode, a saturated $\mathrm{Hg} / \mathrm{Hg}_{2} \mathrm{Cl}_{2}$ electrode (SCE) was used as the reference electrode, and Ti/RuTilrSnMn oxide disk with a diameter of $1 \mathrm{~cm}$ was used as the working electrode. The potentials reported are with respect to the SCE. All the electrochemical measurements were carried out at room temperature. Linear voltammetry was performed in $0.5 \mathrm{M} \mathrm{H}_{2} \mathrm{SO}_{4}$ solutions with and without $1.0 \mathrm{M} \mathrm{NaCl}$ from $0.5 \mathrm{~V}$ to $1.35 \mathrm{~V}$ at a can rate of $1 \mathrm{mV} \mathrm{s}^{-1}$. Cyclic voltammetry was performed in $0.5 \mathrm{M} \mathrm{H}_{2} \mathrm{SO}_{4}+1.0 \mathrm{M} \mathrm{NaCl}$ solutions with and without $200 \mathrm{mg} \mathrm{L}^{-1} \mathrm{~K}-2 \mathrm{BP}$ between $0.5 \mathrm{~V}$ and $1.15 \mathrm{~V}$ at $1 \mathrm{mV} \mathrm{s}$. The cyclic voltammograms reported in this paper are the results of the $5^{\text {th }}$ cycle. Before the experiments, the working electrode was immersed in absolute alcohol for $5 \mathrm{~min}$, rinsed by deionized water and kept in the experimental solutions for $30 \mathrm{~min}$.

\section{Results and Discussion}

\section{Effect of salts}

In order to enhance the diffusion and adsorption of dyestuffs onto the textile, abundant inorganic salts, such as $\mathrm{NaCl}, \mathrm{Na}_{2} \mathrm{SO}_{4}$ and $\mathrm{NaNO}_{3}$, are added into the dyestuff slurries. This technology results in the real textile effluent containing various electrolytes. On the other hand, the existence of salts improves the conductivity of the effluent and reduces the electric energy needed for the electrochemical treatment of the effluent. Therefore, in this paper the effect of various salts on degradation efficiency of $\mathrm{K}-2 \mathrm{BP}$ on Ti/RulrSnMnTi anode was investigated.

As shown in Fig. 3, the decolorization efficiency of K-2BP in both $\mathrm{Na}_{2} \mathrm{SO}_{4}$ and $\mathrm{NaNO}_{3}$ solutions increases slowly and linearly with treatment time. The decolorization efficiency of K-2BP is only $50.9 \%$ after one hour electrolysis in both $\mathrm{Na}_{2} \mathrm{SO}_{4}$ and $\mathrm{NaNO}_{3}$ solutions. However, the decolorization efficiency of $\mathrm{K}-2 \mathrm{BP}$ in $\mathrm{NaCl}$ solution increases drastically in the first 20 min, then increases slowly in the later stage and reaches almost $100 \%$ after $40 \mathrm{~min}$. This indicates that $\mathrm{NaCl}$ favors the degradation of K-2BP. The mechanism can be explained as follows.

In the $\mathrm{NaCl}$-free solution, water is decomposed on the surface of metal oxide anode, producing hydroxyl radicals, and the dye is degraded into $\mathrm{CO}_{2}$ by hydroxyl radicals subsequently (Eqs. 1 and 2):

$$
\begin{aligned}
& \mathrm{H}_{2} \mathrm{O}-\mathrm{e}^{-} \rightarrow \cdot \mathrm{OH}+\mathrm{H}^{+} \\
& \cdot \mathrm{OH}+\text { dye }-\mathrm{e}^{-} \rightarrow \mathrm{H}_{2} \mathrm{O}+\mathrm{H}^{+}+\mathrm{CO}_{2} \uparrow
\end{aligned}
$$

The reaction of water decomposition on anode to form hydroxyl radicals is usually accompanied by the oxygen evolution reaction (Eq. 3), which reduces formation efficiency of the hydroxyl radicals and thus leads to the low degradation efficiency of $\mathrm{K}-2 \mathrm{BP}$ in both $\mathrm{Na}_{2} \mathrm{SO}_{4}$ and $\mathrm{NaNO}_{3}$ solutions.

$$
2 \mathrm{H}_{2} \mathrm{O}-4 \mathrm{e}^{-} \rightarrow 4 \mathrm{H}^{+}+\mathrm{O}_{2} \uparrow
$$




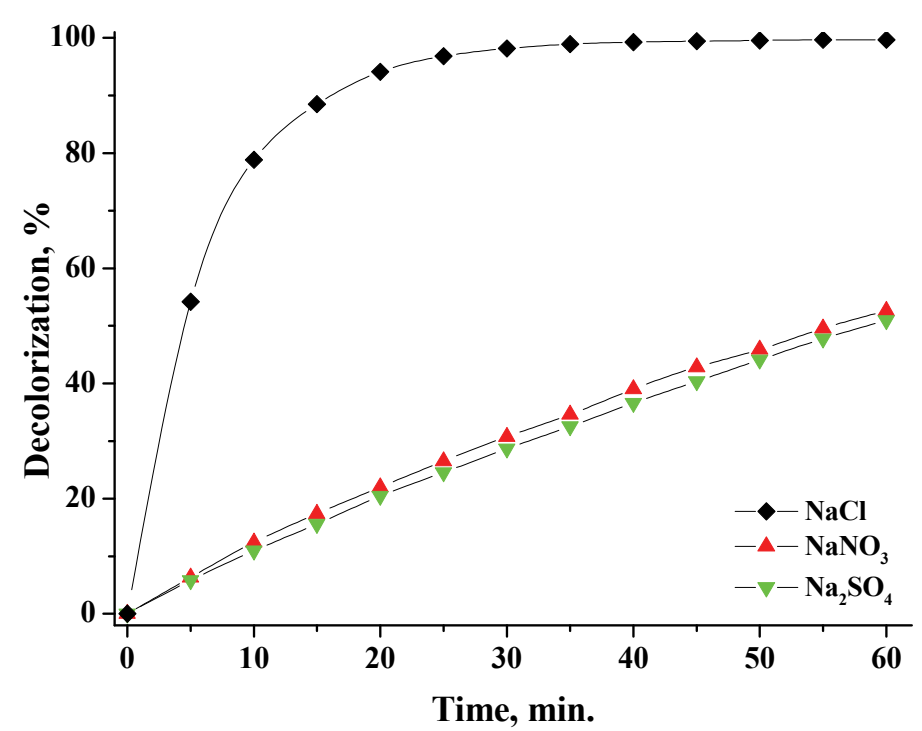

Figure 3. Effect of supporting electrolyte (SE) on the decolorization efficiency of $K-2 B P$.

$$
\text { ( } \mathrm{j}=30 \mathrm{~mA} \mathrm{~cm}{ }^{-2}, \mathrm{c}_{S E}=4.0 \mathrm{~g} \mathrm{~L}^{-1}, \text { flux }=50 \mathrm{~mL} \mathrm{~min}^{-1} \text {, initial } \mathrm{pH}=7.0 \text { ) }
$$

The composite of $\mathrm{Ru}, \mathrm{Ir}, \mathrm{Sn}, \mathrm{Mn}$, and Ti oxides exhibits high activity for the oxidation of chloride ions to form active chlorine. In the $\mathrm{NaCl}$-containing solution, chloride ions are oxidized on this kind of composite oxide anode, forming active chlorine [22,27,29] (Eq. 4).

$$
2 \mathrm{Cl}^{-}-2 \mathrm{e}^{-} \rightarrow \mathrm{Cl}_{2} \uparrow
$$

The active chlorine, electrogenerated in-situ on an anode surface, transforms into a strong oxidant, such as $\mathrm{HClO}$, which oxidizes dyes into small molecules or even carbon dioxide (Eq. 5). Therefore, higher degradation efficiency of the dye on the anode in the $\mathrm{NaCl}$-containing solution can be expected than that in $\mathrm{NaCl}$-free solution.

$$
\mathrm{HClO}+\text { dye (and its oxidation intermediates) } \rightarrow \mathrm{H}_{2} \mathrm{O}+\mathrm{Cl}^{-}+\mathrm{CO}_{2} \uparrow
$$

Fig. 4 presents the linear voltammograms of Ti/RulrSnMnTi oxide electrode in $0.5 \mathrm{M} \mathrm{H}_{2} \mathrm{SO}_{4}$ solution with and without $\mathrm{NaCl}$.

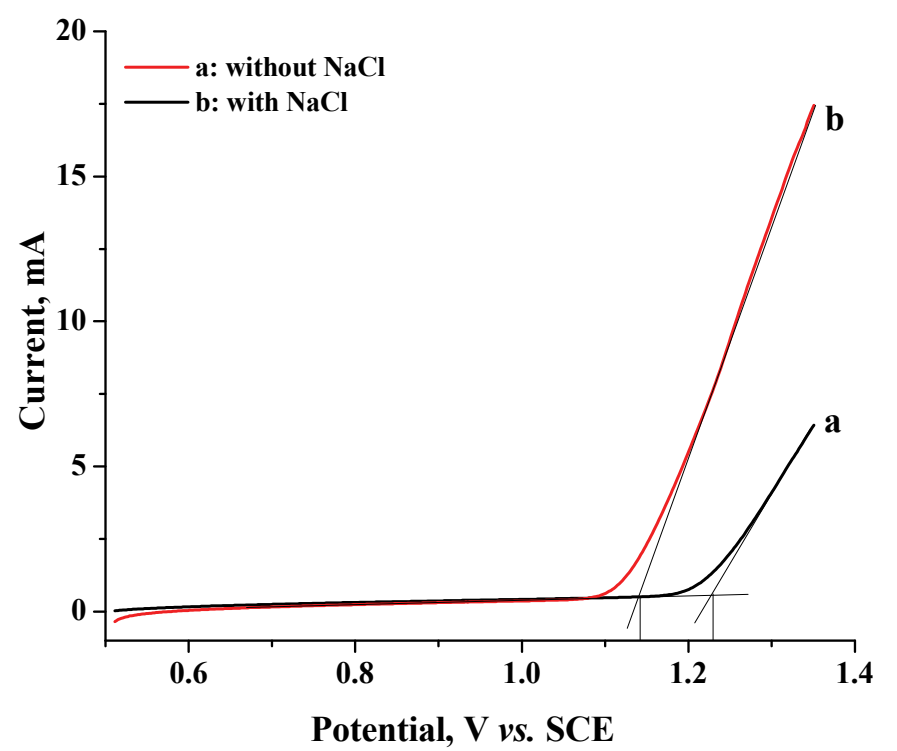

Figure 4. Linear voltammograms of Ti/RulrSnMnTi oxide electrode in the solutions with and without $\mathrm{NaCl}$ 
In the $\mathrm{NaCl}$-free solution, the decomposition potential of water is $1.231 \mathrm{~V}$. However, when chloride ions are added, the decomposition potential shifts negatively to $1.142 \mathrm{~V}$ and the current increases significantly. This indicates that chloride ions can be oxidized more easily on $\mathrm{Ti} /$ RulrSnMnTi oxide electrode than the water decomposition, thus the Ti/RulrSnMnTi oxide shows a good electrocatalytic activity toward the oxidation of chloride ions.

Fig. 5 presents the voltammograms of Ti/RulrSnMnTi oxide electrode in $0.5 \mathrm{M} \mathrm{H}_{2} \mathrm{SO}_{4}+1.0 \mathrm{M}$ $\mathrm{NaCl}$ solutions with and without $200 \mathrm{mg} / \mathrm{L} \mathrm{K}-2 \mathrm{BP}$. For the electrode in the solution without K-2BP, the current increases sharply at the potential higher than $1.1 \mathrm{~V}$ during the forward scanning. Based on the observation of Fig. 4, it follows that the oxidation current is corresponding to the formation of active chlorine from oxidation of chloride ions. Active chlorine can be detected during the backward scanning, as shown by the current peak at about $1.09 \mathrm{~V}$. For the electrode in the solution with $\mathrm{K}-2 \mathrm{BP}$, the current for the oxidation of chloride ions is similar to that in the solution without K-2BP, but the peak current for the reduction of active chlorine is reduced. This suggests that K-2BP is not oxidized directly on the Ti/RulrSnMnTi anode, but indirectly by active chlorine.

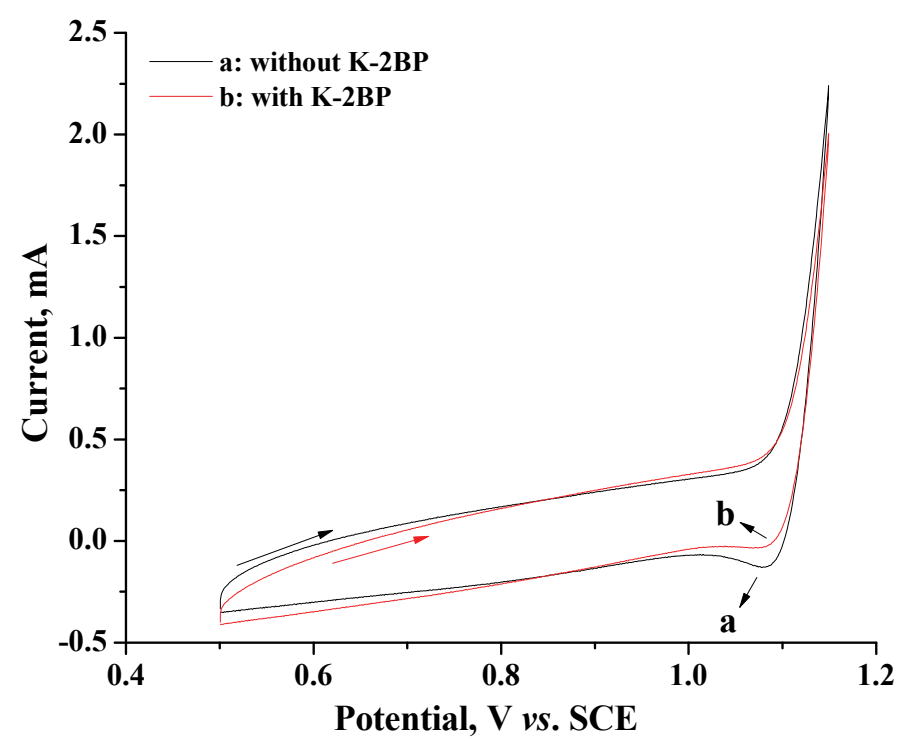

Figure 5. Cyclic voltammograms of Ti/RulrSnMnTi oxide electrode in $0.5 \mathrm{M} \mathrm{H}_{2} \mathrm{SO}_{4}+1.0 \mathrm{M} \mathrm{NaCl}$ solutions with and without $200 \mathrm{mg} \mathrm{L}^{-1} \mathrm{~K}-2 \mathrm{BP}$

\section{Effect of current density}

Charge transfer step is a critical process in electrocatalysis, where the current density at the anode surface determines the rate of the electrode reaction. The effect of current density on the decolorization efficiency was investigated. Fig. 6 presents the obtained results. It can be seen from Fig. 6 that in the first $15 \mathrm{~min}$, when the applied current density rises from 5 to $20 \mathrm{~mA} \mathrm{~cm}{ }^{-2}$, the decolorization efficiency increases drastically from 50 to $85 \%$. There is an optimal decolorization efficiency at $20 \mathrm{~mA} \mathrm{~cm}^{-2}$. A further increase of current density makes no obvious improvement in the decolorization efficiency. This phenomenon can be explained as follows. When the applied current density is low, the production rate of active chlorine is less than its consumption rate for the oxidation of K-2BP, resulting in the low decolorization efficiency. When the applied current density is high, the production rate of active chlorine increases and the decolorization efficiency is improved. As the applied current density increases further, the concentration of chloride ions on anode surface is deficient and active chlorine is no more available for oxidizing the K-2BP. 


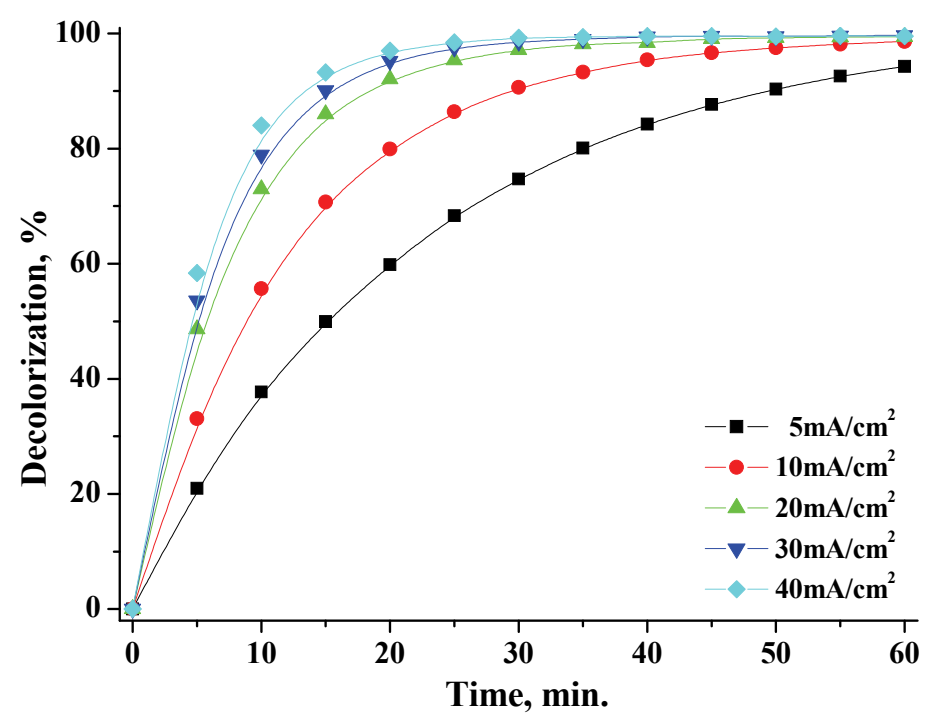

Figure 6. Effect of current density on the decolorization efficiency of $K-2 B P(C N a C l=4.0 \mathrm{~g} / \mathrm{L}$, flux $=50 \mathrm{~mL} / \mathrm{min}$, initial $\mathrm{pH}=7.0$ )

\section{Effect of $\mathrm{NaCl}$ concentration}

Fig. 7 presents the effect of $\mathrm{NaCl}$ concentration on the decolorization of K-2BP. It can be seen from Fig. 7 that in the broad range of $\mathrm{NaCl}$ concentration, from 0.5 to $5.0 \mathrm{~g} \mathrm{~L}^{-1}, \mathrm{~K}-2 \mathrm{BP}$ can be removed completely, even at low $\mathrm{NaCl}$ concentration. For instance, when the dose of $\mathrm{NaCl}$ is $0.5 \mathrm{~g} \mathrm{~L}^{-1}$, the decolorization efficiency reaches $90 \%$ in the first $25 \mathrm{~min}$, and in the later $15 \mathrm{~min}$ the decolorization efficiency reaches $100 \%$. By increasing the dose of $\mathrm{NaCl}$ from 0.5 to $2.0 \mathrm{~g} \mathrm{~L}^{-1}$ the decolorization rate is improved. However, a further increase of the $\mathrm{NaCl}$ dose does not improve the decolorization rate any further.

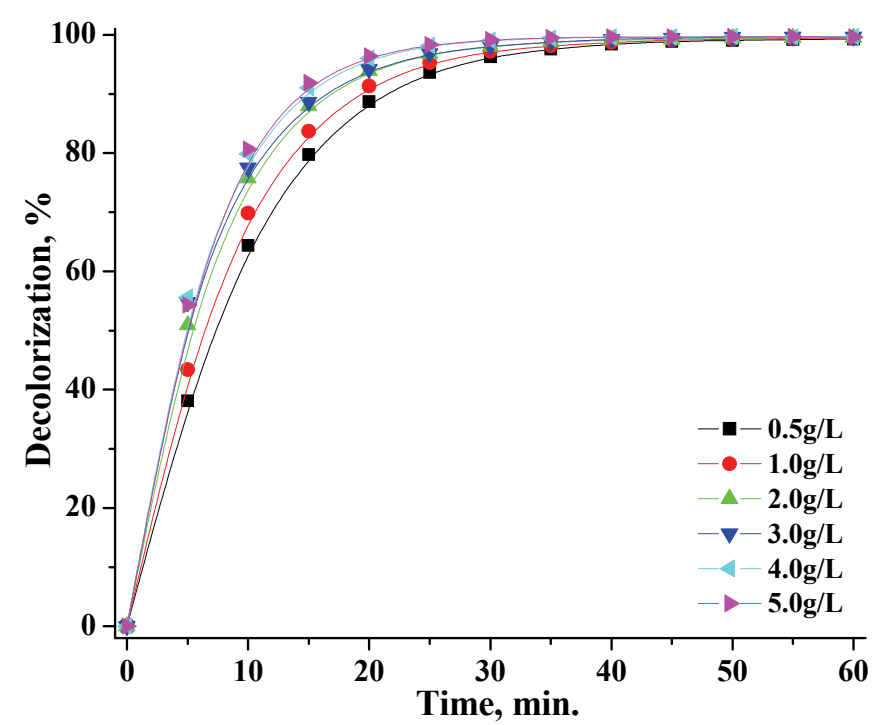

Figure 7. Effect of $\mathrm{NaCl}$ concentration on the decolorization efficiency of $K-2 B P\left(\mathrm{j}=30 \mathrm{~mA} / \mathrm{cm}^{2}\right.$, flux $=50 \mathrm{~mL} / \mathrm{min}$, initial $\mathrm{pH}=7.0$ )

The electrooxidaton process of $\mathrm{K}-2 \mathrm{BP}$ on Ti/RulrSnMnTi anode is determined not only by the charge transfer step, but also by the mass transfer step. At low $\mathrm{NaCl}$ concentration, the production rate of active chlorine is less than its consumption rate with $\mathrm{K}-2 \mathrm{BP}$, leading to low decolorization 
rate. The increase of $\mathrm{NaCl}$ dose can reduce the effect of the mass transfer process and increases the formation rate of active chlorine. When the dose of $\mathrm{NaCl}$ is $2.0 \mathrm{~g} \mathrm{~L}^{-1}$, the formation rate of active chlorine matches the reaction rate between active chlorine and K-2BP. Further increasing of the dose of $\mathrm{NaCl}$ does not increase the decolorization rate, because the formation of active chlorine is controlled by the charge transfer step.

\section{Effect of initial $\mathrm{pH}$}

Fig. 8 presents the effect of the initial $\mathrm{pH}$ of the solution on the decolorization efficiency. As shown in Fig. 8, the initial $\mathrm{pH}$ of the solution affects the decolorization efficiency of K-2BP significantly. In the $\mathrm{pH}$ range between 1.0 and 11.0 , the decolorization efficiency of K-2BP increases with the decrease of the initial $\mathrm{pH}$ of the solution.

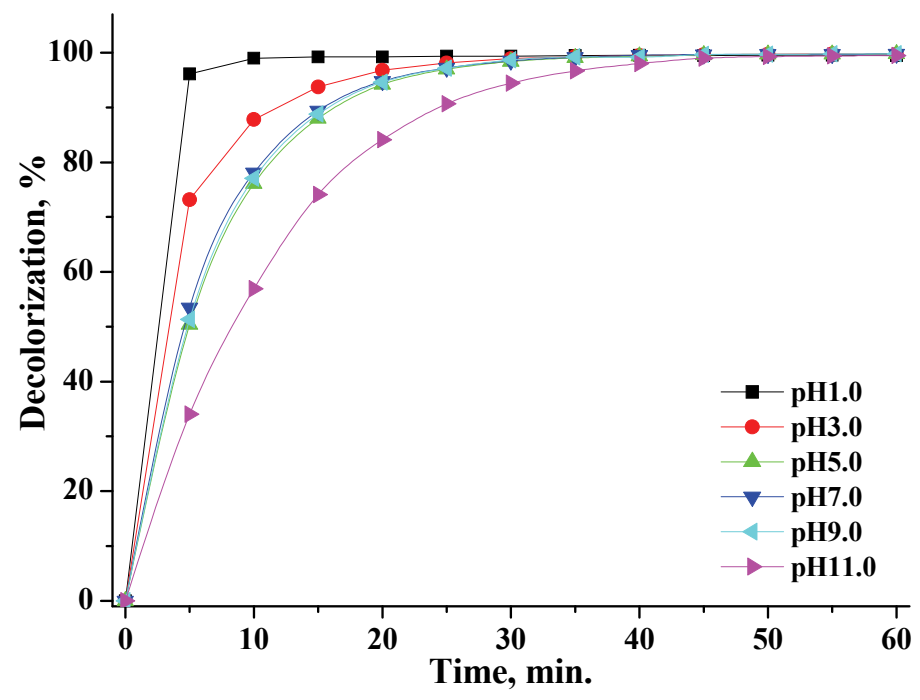

Figure 8. Effect of initial $\mathrm{pH}$ on the decolorization efficiency of $K-2 B P\left(\mathrm{j}=30 \mathrm{~mA} / \mathrm{cm}^{2}\right.$, $c_{\text {NaCl }}=4.0 \mathrm{~g} / \mathrm{L}$, flux $=50 \mathrm{~mL} / \mathrm{min}$ )

In aqueous solution, the active chlorine in-situ electrogenerated is in the form of hypochlorous acid and hypochlorite ion, which reach an equilibrium (Eq. 6):

$\mathrm{HClO} \rightleftarrows \mathrm{ClO}^{-}+\mathrm{H}^{+}$

According to the Le Chatelier's principle, the increase of the hydrogen ion concentration shifts the equilibrium to the left in favor of forming hypochlorous acid. The standard formation potential of hypochlorous acid and hypochlorite ion is $1.49 \mathrm{~V}$ and $0.81 \mathrm{~V}$, respectively, and the potential is a function of hydrogen ion concentration in solution (Eqs. 7 and 8):

$$
\begin{aligned}
& \varphi\left(\mathrm{HClO}^{-\mathrm{Cl}^{-}}\right)=\varphi^{\theta}\left(\mathrm{HClO}^{-\mathrm{Cl}^{-}}\right)+\mathrm{RT} / 2 \mathrm{~F} \ln \left(\left[\mathrm{H}^{+}\right]\left[\mathrm{HClO}^{-} /\left[\mathrm{Cl}^{-}\right]\right)\right. \\
& \varphi\left(\mathrm{ClO}^{-} / \mathrm{Cl}^{-}\right)=\varphi^{\theta}\left(\mathrm{ClO}^{-} / \mathrm{Cl}^{-}\right)+\mathrm{RT} / 2 \mathrm{~F} \ln \left(\left[\mathrm{ClO}^{-}\right] /\left[\mathrm{OH}^{-}\right]^{2}\left[\mathrm{Cl}^{-}\right]\right)
\end{aligned}
$$

Therefore, oxidative ability of hypochlorous acid is much stronger than of hypochlorite ion, and the smaller the value of $\mathrm{pH}$ is, the stronger is the oxidative ability of hypochlorous acid [30,34-37].

\section{Effect of flow rate}

The effect of solution flow rate on decolorization efficiency of K-2BP was considered in the range from 10 to $70 \mathrm{ml} \mathrm{min}^{-1}$. Fig. 9 presents the obtained results. It can be seen from Fig. 9 that decolorization efficiency increases as the flow rate increases from 10 to $50 \mathrm{ml} \mathrm{min}^{-1}$. Further increase in the flow rate does not affect the decolorization efficiency significantly. Apparently, the 
formation process of active chlorine is also controlled by the diffusion of chloride ions. The diffusion layer thickness is proportional to the flow rate, i.e. the faster flow rate favors the diffusion of chloride ions to the electrode surface. However, at high flow rate, turbulent flow appears and the effect of flow rate cannot be observed.

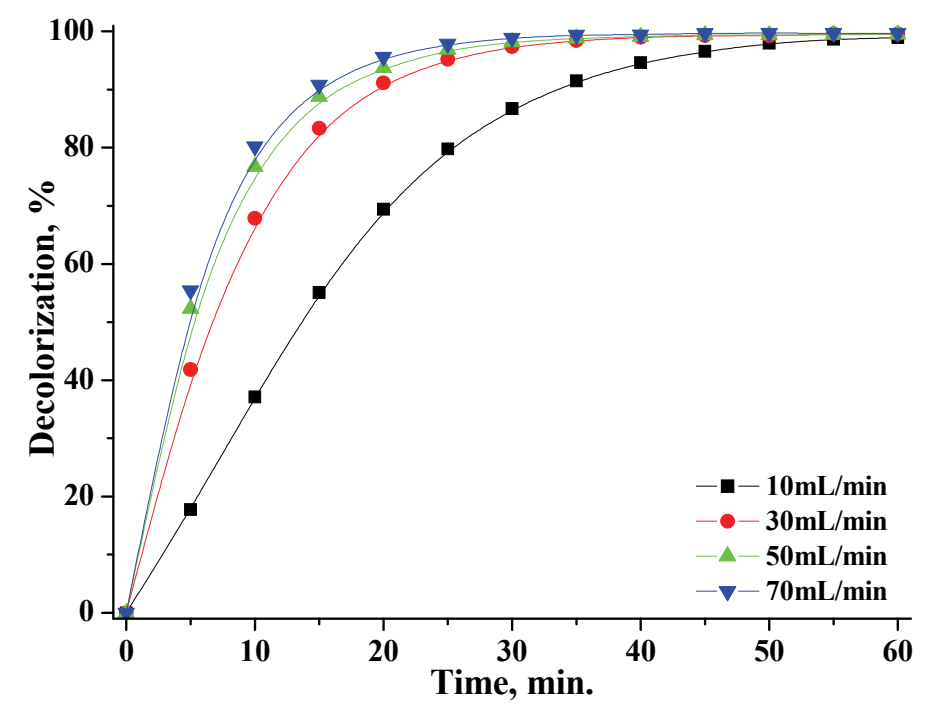

Figure 9. Effect of flow rate on the decolorization efficiency of $K-2 B P$

$$
\text { (j }=30 \mathrm{~mA} \mathrm{~cm}^{-2}, \mathrm{c}_{\mathrm{NaCl}}=4.0 \mathrm{gL}^{-1} \text {, initial } \mathrm{pH}=7.0 \text { ) }
$$

\section{Effect of temperature}

Fig. 10 presents the effect of temperature on the decolorization efficiency of K-2BP. As shown in Fig. 10 the increasing temperature leads to the enhancement of the decolorization efficiency. The time of complete decolorization is $35 \mathrm{~min}$ at $303 \mathrm{~K}$, while it reduces to $20 \mathrm{~min}$ at $343 \mathrm{~K}$. The enhancement of decolorization efficiency of K-2BP can be ascribed to the improvement of the charge transfer rate and the reaction rate of the active chlorine with $\mathrm{K}-2 \mathrm{BP}$ in the solution.

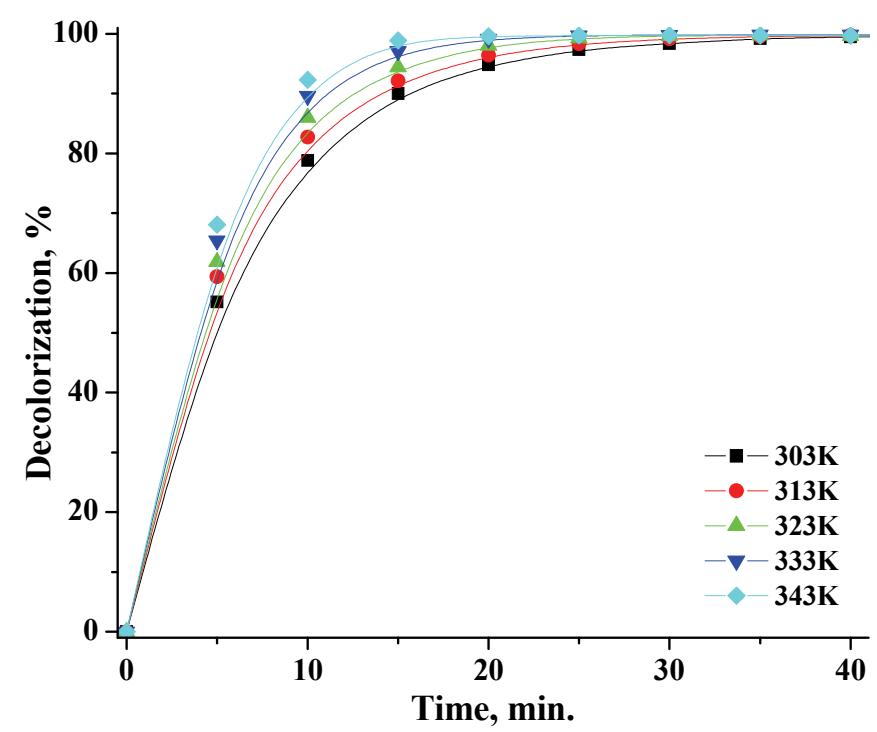

Figure 10. Effect of temperature on the decolorization efficiency of $K-2 B P$ ( $\mathrm{j}=30 \mathrm{~mA} \mathrm{~cm}^{-2}, \mathrm{c}_{\mathrm{NaCl}}=4.0 \mathrm{~g} \mathrm{~L}^{-1}$, flux $=50 \mathrm{~mL} \mathrm{~min}-1, \mathrm{pH}=7.0$ ) 


\section{Reaction kinetics}

The variation of K-2BP concentration (absorbance) with time at different temperatures was modeled by the zero order, the first order and the second order reaction. The obtained results are shown in Table 1. It can be seen from Table 1 that the correlation coefficient (R2) of the first order kinetics model is about 0.999, far higher than those of zero and second order models. This indicates that the decolorization process of K-2BP follows the pseudo-first-order kinetics. Therefore, the decolorization rate equation can be expressed by (Eq. 9):

$$
\ln \frac{c_{\mathrm{t}}}{C_{0}}=\ln \frac{A_{\mathrm{t}}}{A_{0}}=-K_{\mathrm{obs}} t
$$

where $t$ is the reaction time $(\mathrm{min}), c_{0}$ and $c_{\mathrm{t}}$ are the concentrations $\left(\mathrm{mg} \mathrm{L}^{-1}\right.$ ) of K-2BP at the initial and at $t, A_{0}$ and $A_{\mathrm{t}}$ are the absorbance of $\mathrm{K}-2 \mathrm{BP}$ at the initial and at $t$, and $K_{\mathrm{obs}}$ is the pseudo-firstorder kinetic constant $\left(\mathrm{min}^{-1}\right)$.

Table 1. Results of fitting of the kinetics equation for zero-order, first-order and second-order of Reactive Brilliant Red K-2BP at various temperatures

\begin{tabular}{|c|c|c|c|c|}
\hline \multirow{2}{*}{ Temperature, $\mathrm{K}$} & \multirow{2}{*}{$\frac{\text { zero order }}{\mathrm{R}^{2}}$} & \multirow{2}{*}{$\frac{\text { second order }}{\mathrm{R}^{2}}$} & \multicolumn{2}{|c|}{ first order } \\
\hline & & & $\mathrm{R}^{2}$ & $K_{\text {obs }} / \min ^{-1}$ \\
\hline 303 & 0.84361 & 0.91002 & 0.99933 & 0.15119 \\
\hline 313 & 0.79883 & 0.87378 & 0.99946 & 0.16941 \\
\hline 323 & 0.76557 & 0.79324 & 0.99987 & 0.19533 \\
\hline 333 & 0.71530 & 0.71310 & 0.99903 & 0.23650 \\
\hline 343 & 0.67154 & 0.71861 & 0.99574 & 0.28096 \\
\hline
\end{tabular}

Fig. 11 shows the linear relationship between the decolorization time $t$ and $\ln \left(A_{t} / A_{0}\right)$. Fig. 12 presents the relationship between rate constant $K_{\text {obs }}$ and temperature. It can be seen that the rate constant increases with temperature.

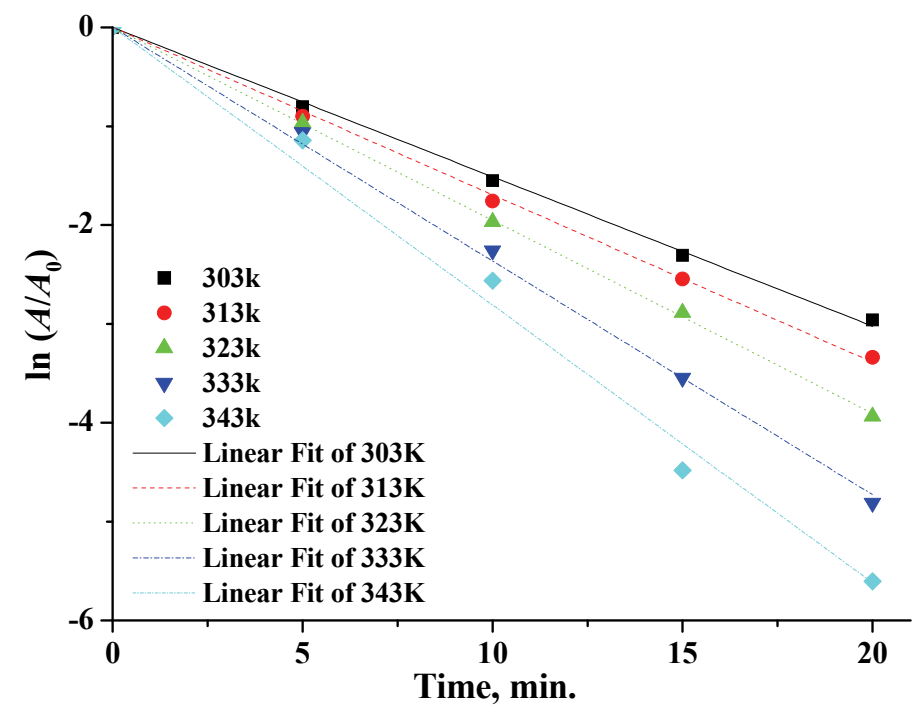

Figure 11. First-order kinetic fitting results of decolorization rate of $K-2 B P$ at various temperatures 


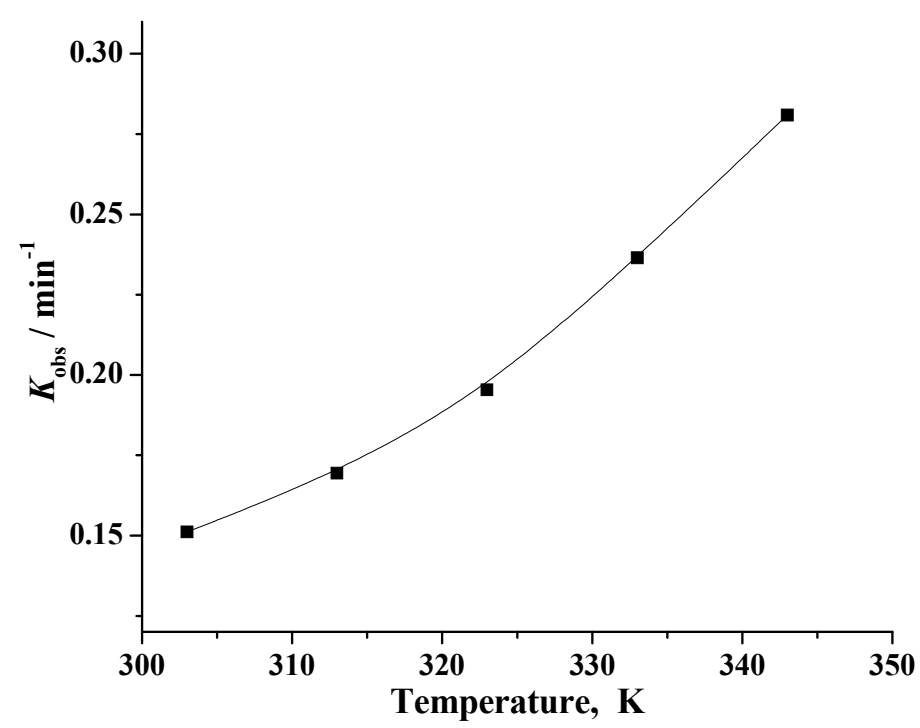

Figure 12. Relationship between rate constant $\mathrm{K}_{\text {obs }}$ and temperature

\section{UV-visible spectroscopy}

In K-2BP there are aromatic rings, naphthalene rings, triazine rings and $-\mathrm{N}=\mathrm{N}-$ groups. $-\mathrm{N}=\mathrm{N}-$ is the chromophore group and the bridge between the aromatic ring and naphthalene to form a big bond conjugate system. Fig. 13 presents the variation of K-2BP UV-visible spectrum with time. K$2 \mathrm{BP}$ is characterized by three absorbance peaks of $235 \mathrm{~nm}, 285 \mathrm{~nm}$ and $370 \mathrm{~nm}$ in ultraviolet region and only one peak of $520 \mathrm{~nm}$ in visible region. The absorbance in the visible region should be ascribed to the chromophore group of $-\mathrm{N}=\mathrm{N}-$, and the absorbance in ultraviolet region should be ascribed to the aromatic ring, triazine ring and naphthalene ring, respectively [38-40]. It can be seen from Fig. 13 that the intensity of all the absorbance peaks decreases rapidly with time and these peaks disappear completely in $30 \mathrm{~min}$. This indicates that in the $\mathrm{NaCl}$-containing solution, $\mathrm{Ti} / \mathrm{RulrSnMnTi}$ anode can remove the color of K-2BP completely, and the triazine ring, aromatic ring and naphthalene ring can be cleaved into aliphatic acid with low molecular weight or even completely mineralized.

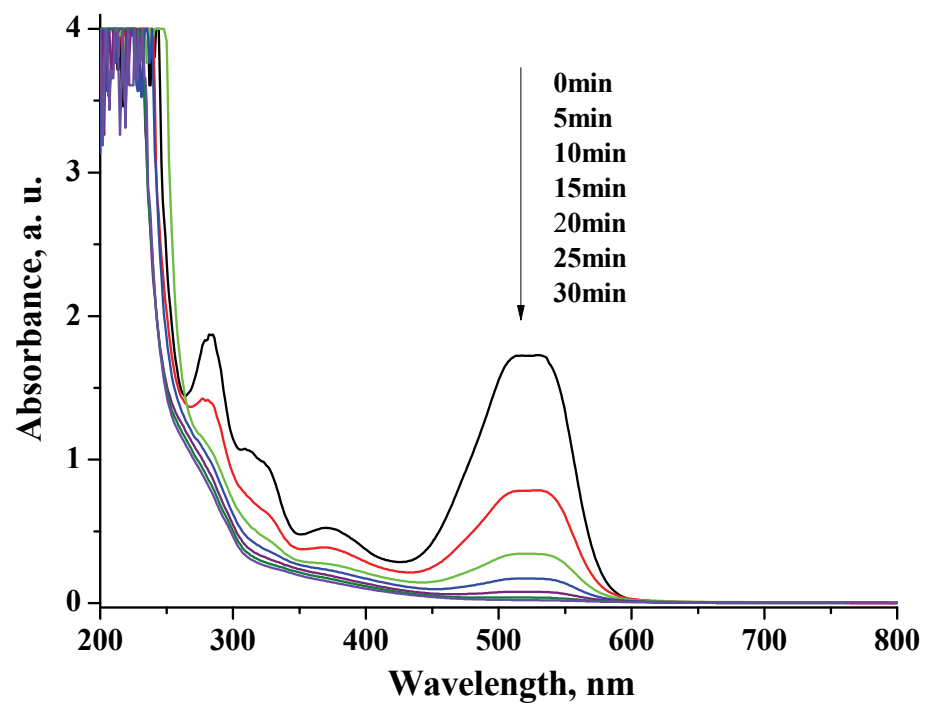

Figure 13. UV-Vis spectrum variation of $\mathrm{K}-2 \mathrm{BP}$ during electrolysis in $\mathrm{NaCl}$ solution 


\section{Conclusions}

$\mathrm{Ti} / \mathrm{RulrSnMnTi}$ oxide anode can be used to degrade Reactive Brilliant Red K-2BP effectively in the solution containing chloride ions. The degradation mechanism of K-2BP is an indirect electrocatalytic oxidation, in which K-2BP is oxidized by the electrogenerated active chlorine. This degradation reaction follows pseudo-fist-order-reaction kinetics and can be improved by increasing current density and $\mathrm{NaCl}$ concentration, enhancing the temperature and flow rate, and lowering the $\mathrm{pH}$ of the solution.

Acknowledgements: This work was financially supported by Natural Science Foundation of Guangdong Province (Grant No. 10351063101000001) and Combination Project of Enterprise, University and Scientific Research of Guangdong Province (Grant No. 2010B090400019).

\section{References}

[1] H. Salvado, M.P. Gracia, J.M. Amigó, Water Res. 29 (1995) 1041-1050.

[2] W. Fuchs, C. Resch, M. Kernstock, M. Mayer, P. Schoeberl, R. Braun, Water Res. 39 (2005) 803-810.

[3] K.C.A. Bromley-Challenor, J.S. Knapp, Z. Zhang, N.C.C. Gray, M.J. Hetheridge, M.R. Evans, Water Res. 34 (2000) 4410-4418.

[4] S. Chinwetkitvanich, M. Tuntoolvest, T. Panswad, Water Res. 34 (2000) 2223-2232.

[5] A.B. Dos-Santos, F.J. Cervantes, R.E. Yaya-Beas, J.B. van Lier, Enzyme Microb. Tech. 33 (2003) 942-951.

[6] T. Panswad, K. lamsamer, J. Anotai, Bioresource Technol. 76 (2001) 151-159.

[7] C.T.M.J. Frijters, R.H. Vos, G. Scheffer, R. Mulder, Water Res. 40 (2006) 1249-1257.

[8] J.F. Lei, W.S. Li, Acta Phys. Chim. Sin. 25 (2009) 1173-1178.

[9] I. Peternel, N. Koprivanac, H. Kušić, Water Res. 40 (2006) 525-532.

[10] A. Vijayabalan, K. Selvam, R. Velmurugan, M. Swaminathan, J. Hazard. Mater. 172 (2009) 914-921.

[11] J.N. Wu, T.W. Wang, Water Res. 35 (2001) 1093-1099.

[12] T.Y. Chen, C.M. Kao, A. Hong, C.E. Lin, S.H. Liang, Desalination 249 (2009) 1238-1242.

[13] G.H. Chen, L.C. Lei, P. Yue, Ind. Eng. Chem. Res. 38 (1999) 1837-1843.

[14] A. Santos, P. Yustos, S. Rodriguez, F. Garcia-Ochoa, M. de Garcia, Ind. Eng. Chem. Res. 46 (2007) 2423-2427.

[15] I. Gulkaya, G.A. Surucu, F.B. Dilek, J. Hazard. Mater. 136 (2006) 763-769.

[16] C.T. Wang, J.L. Hu, W.L. Chou, Y.M. Kuo, J. Hazard. Mater. 152 (2008) 601-606.

[17] A.H. Essadki, M. Bennajah, B. Gourich, C. Vial, M. Azzi, H. Delmas, Chem. Eng. Process. 47 (2008) 1211-1223.

[18] X.D. Zhang, J.D. Hao, W.S. Li, H.J. Jin, J. Yang, Y.M. Huang, D.S. Lu, H.K. Xu, J. Hazard Mater. 170 (2009) 883-887.

[19] W. Balla, A.H. Essadki, B. Gourich, A.Dassaa, H. Chenik, M. Azzi, J. Hazard. Mater. 184 (2010) 710-716.

[20] M. Panizza, G. Cerisola, Water Res. 40 (2006) 1179-1184.

[21] M. Panizza, G. Cerisola, Environ. Sci. Technol. 38 (2004) 5470-5475.

[22] Z.C. Wu, M.H. Zhou, Environ. Sci.Technol. 35 (2001) 2698-2703.

[23] M.H. Zhou, Q.Z. Dai, L.C. Lei, C.Ma, D. Wang, Environ. Sci.Technol. 39 (2005) 363-370.

[24] M. Li, C.P. Feng, W.W. Hu, Z. Zhang, N. Sugiura, J. Hazard. Mater. 162 (2009) 455-462.

[25] J.B. Parsa, M. Rezaei, A.R. Soleymani, J. Hazard. Mater. 168 (2009) 997-1003.

[26] S.S. Vaghela, A.D. Jethva, B.B. Mehta, S.P. Dave, S. Adimurthy, G. Ramachandraiah, Environ. Sci. Technol. 39 (2005) 2848-2855. 
[27] S. Song, J.Q. Fan, Z.Q. He, L. Chan, Z. Liu, J. Chen, X. Xu, Electrochim. Acta 55 (2010) 36063613.

[28] B.J. Hernlem, Water Res. 39 (2005) 2245-2252.

[29] P. Canizares, J.A. Dominguez, M.A. Rodrigo, J. Villasenor, J. Rodriguez, Ind. Eng. Chem. Res. 38 (1999) 3779-3785.

[30] H.X. Shi, J.H. Qu, A.M. Wang, J.T. Ge, Chemosphere 60 (2005) 326-333.

[31] C.R. Costa, P. Olivi, Electrochim. Acta 54 (2009) 2046-2052.

[32] C.A. Martinez-Huitle, A. Battisti, S. Ferro, S. Reyna, M. Cerro-Lopez, M.A. Quiro, Environ. Sci. Technol. 42 (2008) 6929-6935.

[33] S. Trasatti, Electrochim. Acta 45 (2000) 2377-2385.

[34] A. Maljaei, M. Arami, N.M. Mahmoodi, Desalination 249 (2009) 1074-1078.

[35] O. Scialdone, S. Randazzo, A. Galia, G. Silvestri, Water Res. 43 (2009) 2260-2272.

[36] S. Raghu, C.A. Basha, Ind. Eng. Chem. Res. 47 (2008) 5277-5283.

[37] L. Szpyrkowicz, C. Juzzolino, S.N. Kaul, S. Daniele, M.D. De Faveri Ind. Eng. Chem. Res. 39 (2000) 3241-3248.

[38] X.N. Wang, J.P. Jia, Y.L. Wang, Ultrason. Sonochem. 17 (2010) 515-520.

[39] J. Yang, J. Wang, J.P. Jia, Environ. Sci. Technol. 43 (2009) 3796-3802.

[40] X.J. Lu, B. Yang, J.H. Chen, R.Sun, J. Hazard. Mater. 161 (2009) 241-245.

(C) 2012 by the authors; licensee IAPC, Zagreb, Croatia. This article is an open-access article distributed under the terms and conditions of the Creative Commons Attribution license (http://creativecommons.org/licenses/by/3.0/) (cc) EY 